\title{
PENGARUH KOMPETENSI PROFESIONAL GURU TERHADAP KINERJA GURU DI SMA NEGERI 01 KALISAT TAHUN PELAJARAN 2018/2019
}

\author{
Faizzatul Himmah ${ }^{1}$, Sukidin ${ }^{1}$, Titin Kartini ${ }^{1}$ \\ ${ }^{1}$ Program Studi Pendidikan Ekonomi, Fakultas Keguruan dan Ilmu Pendidikan, Universitas Jember \\ e-mail: faizhimmah21@gmail.com
}

\begin{abstract}
Abstrak
Penelitian ini bertujuan untuk mengetahui berapa besar pengaruh kompetensi profesional guru terhadap kinerja guru di SMA Negeri 01 Kalisat. penelitian ini merupakan penelitian deskriptif dengan menggunakan pendekatan kuantitatif. Subjek penelitian ini adalah para guru PNS dan Non PNS yang terserifikasi di SMA Negeri 01 Kalisat, sedangkan informan penelitian ini adalah kepala sekolah SMA Negeri 01 Kalisat. metode pengumpulan data yang digunakan adalah metode angket, wawancara, obeservasi dan dokumentasi. Metode analisis data yang digunakan adalah analisis garis regresi sederhana berupa uji $\mathrm{F}$, koefisien korelasi dan koefisien determinasi. Hasil penelitian ini menunjukkan F hitung $=213,767>\mathrm{F}$ tabel $=$ 4,113 dengan nilai $\alpha=0,05>\operatorname{sig}$ F 0,000 maka terdapat pengaruh kompetnsi profesional guru terhadap kinerja guru di SMA Negeri Kalisat. hasil koefisien korelasi menunjukkan angka 0,925 yang artinya hubungan antara variabel kompetensi profesional guru dengan kinerja guru di SMA Negeri 01 Kalisat sangat kuat. Hasil koefisien determinasi menunjukkan besarnya persentase pengaruh kompetensi profesional guru terhadap kinerja guru di SMA Negeri 01 Kalisat ialah sebesar 85,6\%. Sedangkan 14,4\% sisanya ialah dipengaruhi oleh faktor-faktor lain yang tidak diteliti dalam penelitian ini.
\end{abstract}

Kata Kunci: kompetensi guru, Komepetensi Profesional guru, Kinerja Guru

\section{PENDAHULUAN}

Guru merupakan salah satu profesi yang bertujuan untuk menciptakan sumber daya manusia yang berkualitas. Sumber daya manusia dikelola melalui pendidikan. Keberadaan guru dalam dunia pendidikan mempunyai peran dan tanggung jawab yang sangat vital, yakni mengajar dan mendidik. Sehingga sangat wajar jika guru dikatakan sebagai ujung tombak dalam mencerdaskan bangsa. Hal ini mengisyaratkan bahwa guru menjadi ikon penting yang bertugas merubah masa depan bangsa ke arah lebih baik.

Berdasarkan Peraturan Menteri Pendidikan Nasional Republik Indonesia No. 16 Tahun 2007 tentang Standar Kualifikasi Akademik dan Kompetensi Guru, menyatakan bahwa seorang guru harus memiliki empat komponen dasar, yaitu kompetensi pedagogik, kompetensi profesional, kompetensi sosial, dan kompetensi kepribadian. Keempat kompetensi tersebut harus dimiliki oleh setiap tenaga pendidik agar dapat melaksanakan tugasnya sebagai pendidik yang profesional dan tujuan luhur untuk menciptakan sumber daya manusia yang berkualitas dapat tercapai secara maksimal.

Tujuan dari pendidikan dan pembelajaran yang dilakukan oleh seorang guru tidak serta-merta hanya ingin membekali peserta didik berbagai macam ilmu dan teknologi bagi diri mereka sendiri saja. Akan tetapi, pendidikan diharapkan dapat mengantar peserta didik mengenal, memahami diri mereka sendiri dan menghargai orang lain dengan baik, sehingga mereka dapat hidup bersama dikalangan masyarakat yang heterogen dan multikultur.

Demi tercapainya hal-hal tersebut diatas, diperlukan adanya komponen yang mendukung salah satunya adalah kinerja guru yang tinggi. Kinerja guru merupakan kunci dri keberhasilan mewujudkan tujuan pendidikan. Terdapat beberapa hal yang dapat mempengaruhi tingkat kinerja guru diantaranya kompetensi guru dalam kegiatan belajar mengajar. Kompetensi adalah suatu yang mutlak dimiliki oleh seorang guru dalam kegitan pengelolaan pembelajaran, agar mampu menciptakan lingkungan belajar yang efektif. Berdasarkan hasil observasi di SMA Negeri 01 Kalisat kompetensi guru dinilai baik. Guru mengajar sesuai dengn bidang keahlian yang dimiliki, melaksanakan kegiatan pembelajaran sesuai kurikulum yang berlaku, dan mampu menggunakan sarana prasarana yang memadai. 
Untuk meningkatkan keaktifan guru-guru dalam melaksanakan tugas mengajarnya, diadakan rapat rutin disetiap bulan, mengadakan MGMP (musyawarah guru mata pelajaran), seminar dan berbagai workshop perkembangan kurikulum yang berlaku. Kegitan-kegiatan tersebut diharapkan dapat meningkatkan kompetensi guru yang akan berpengaruh pula pada kinerja guru di SMA 01 Negeri Kalisat.

Kompetensi guru yang baik tentunya akan memberikan pengaruh yang baik pula terhadap kinerja seorang guru. Namun kenyataan dilapangan masih ada beberapa guru yang kinerjanya belum optimal, seperti halnya di SMA Negeri Kalisat. Berdasarkan latar belakang diatas, peneliti tertarik untuk melakukan penelitian dengan judul "Pengaruh Kompetensi Profesionl Guru terhadap Kinerja Guru di SMA Negeri 01 Kalisat Tahun Pelajaran 2018/2019"

\section{METODE}

Penelitian ini menggunakan jenis penelitian deskriptif dengan pendekatan kuantitatif. Lokasi penelitian ini dilaksanakan di SMA Negeri 01 Kalisat. Penentuan lokasi penelitian ini menggunakan metode purposive area yaitu lokasi penelitian yang ditentukan secara sengaja. Subjek dalam penelitian ini adalah para guru PNS dan Non PNS yang terserifikasi di SMA Negeri 01 Kalisat, sedangkan informan penelitian ini adalah kepala sekolah SMA Negeri 01 Kalisat. metode pengumpulan data yang digunakan adalah metode angket, wawancara, obeservasi dan dokumentasi. Metode analisis data yang digunakan adalah analisis garis regresi sederhana berupa uji F, koefisien korelasi dan koefisien determinasi

\section{HASIL DAN PEMBAHASAN Hasil Penelitian}

Hasil penelitian ini menunjukkan $\mathrm{F}$ hitung $=213,767>\mathrm{F}$ tabel $=4,113$ dengan nilai $\alpha=0,05>$ sig F 0,000 maka terdapat pengaruh kompetnsi profesional guru terhadap kinerja guru di SMA Negeri Kalisat. hasil koefisien korelasi menunjukkan angka 0,925 yang artinya hubungan antara variabel kompetensi profesional guru dengan kinerja guru di SMA Negeri 01 Kalisat sangat kuat. Hasil koefisien determinasi menunjukkan besarnya persentase pengaruh kompetensi profesional guru terhadap kinerja guru di SMA Negeri 01 Kalisat ialah sebesar 85,6\%. Sedangkan 14,4\% sisanya ialah dipengaruhi oleh faktor-faktor lain yang tidak diteliti dalam penelitian ini.

\section{Pembahasan}

Kompetensi profesional guru dalam penelitian ini menggunakan 5 indikator yaitu 1) penguasaan materi, 2) penguasaan standar kompetensi dan kompetensi dasar, 3) pengembangan materi, 4) pengembangan diri dan 5) pemanfaatan TIK. Pada lembar angket terdapat 16 item pertanyaan dengan skala penilaian sangat baik, baik, cukup dan kurang.

Kinerja guru dalam penelitian ini menggunakan 3 indikator yaitu 1) perencanaan pembelajaran, 2) pelaksanaan pembelajaran, dan 3) pelaksanaan evaluasi pembelajaran. Pada lembar angket terdapat 53 item pertanyaan dengan skala penilaian sangat baik, baik, cukup dan kurang.

Hasil penelitian menunjukkan $\mathrm{F}$ hitung $=213,767>\mathrm{F}$ tabel $=4,113$ dengan nilai $\alpha=0,05>\operatorname{sig} \mathrm{F}$ 0,000 maka Ha diterima. Berdasarkan hal tersebut dapat disimpulkan bahwa variabel kompetensi profesional guru berpengaruh secara signifikan terhadap variabel kinerja guru di SMA Negeri 01 Kalisat. Analisis koefisien korelasi digunakan untuk mengetahui kuat tidaknya atau untuk mengetahui tingkat keeratan variabel bebas kompetensi profesional guru terhadap variabel terikat yakni kinerja guru di SMA Negeri 01 Kalisat. Besarnya koefisien korelasi sebesar 0,925. Artinya variabel kompetensi profesional guru $(\mathrm{X})$ memiliki hubungan yang nyata dengan variabel kinerj guru di SMA Negeri 01 Kalisat. Hasil perhitungan koefisien korelasi variabel kompetensi profesional guru terhadap kinerja guru di SMA Negeri 01 Kalisat termasuk pada nilai interpretasi koefisien 0,800 - 1,000. Artinya hubungan antara variabel kompetensi profesional guru dengan kinerja guru di SMA Negeri 01 Kalisat sangat kuat. Koefisien determinasi menunjukkan besarnya persentase pengaruh kompetensi profesional guru terhadap kinerja guru di SMA Negeri 01 Kalisat adalah sebesar 85,6\%, sedangkan sisanya $14,4 \%$ merupakan faktor-faktor lain yang tidak diteliti dalam penelitian ini seperti kompetensi 
pedagogik, kompetensi sosial dan kompetensi individu.

\section{PENUTUP}

Berdasarkan pembahasan hasil penelitian dapat diketahui bahwa hasil penelitian ini menunjukkan $\mathrm{F}$ hitung $=213,767>\mathrm{F}$ tabel $=4,113$ dengan nilai $\alpha=0,05>\operatorname{sig} \mathrm{F} 0,000$ maka terdapat pengaruh kompetnsi profesional guru terhadap kinerja guru di SMA Negeri Kalisat. hasil koefisien korelasi menunjukkan angka 0,925 yang artinya hubungan antara variabel kompetensi profesional guru dengan kinerja guru di SMA Negeri 01 Kalisat sangat kuat. Hasil koefisien determinasi menunjukkan besarnya persentase pengaruh kompetensi profesional guru terhadap kinerja guru di SMA Negeri 01 Kalisat ialah sebesar 85,6\%. Sedangkan 14,4\% sisanya ialah dipengaruhi oleh faktorfaktor lain yang tidak diteliti dalam penelitian ini.

Saran yang dapat diberikan adalah Bagi kepala sekolah untuk terus melakukan penilaian berkala terhadap kompetensi profesional guru. Sehingga guru akan senantiasa meningkatkan kompetensi profesional dan kinerjanya.

\section{DAFTAR PUSTAKA}

Depdikbud. 1991. Kamus Besar Bahasa Indonesia, Jakarta: Balai Pustaka

Suyono dan Hariyanto. 2014. Belajar dan Pembelajaran : Teori dan Konsep Dasar. Bandung. PT

Remaja Rosdakarya Offset. 